\title{
Context and Opportunities for Expanding Protected Areas in Canada
}

\author{
Michael A. Wulder ${ }^{1, *(\mathbb{D}}$, Jeffrey A. Cardille ${ }^{2}$, Joanne C. White ${ }^{1(\mathbb{C}}$ and Bronwyn Rayfield ${ }^{3(\mathbb{D}}$ \\ 1 Canadian Forest Service (Pacific Forestry Centre), Natural Resources Canada, Victoria, BC V8Z 1M5, Canada; \\ joanne.white@canada.ca \\ 2 Department of Natural Resource Sciences and McGill School of Environment, McGill University, \\ Ste. Anne de Bellevue, QC H9X 3V9, Canada; jeffrey.cardille@mcgill.ca \\ 3 Apex Resource Management Solutions Ltd., Ottawa, ON K2A 3K2, Canada; bronwynrayfield@gmail.com \\ * Correspondence: mike.wulder@canada.ca
}

Received: 25 September 2018; Accepted: 7 November 2018; Published: 15 November 2018

check for updates

\begin{abstract}
At present, 10.5\% of Canada's land base is under some form of formal protection. Recent developments indicate Canada aims to work towards a target of protecting $17 \%$ of its terrestrial and inland water area by 2020. Canada is uniquely positioned globally as one of the few nations that has the capacity to expand the area under its protection. In addition to its formally protected areas, Canada's remote regions form de facto protected areas that are relatively free from development pressure. Opportunities for expansion of formally protected areas in Canada include official delineation and designation of de facto protected areas and the identification and protection of land to improve connectivity between protected areas (PAs). Furthermore, there are collaborative opportunities for expanding PA through commitments from industry and provincial and territorial land stewards. Other collaborative opportunities include the contributions of First Nations aligning with international examples of Indigenous Protected Areas, or the incorporation and cultivation of private protection programs with documented inclusion in official PA networks. A series of incremental additions from multiple actors may increase the likelihood for achieving area-based targets, and expands stakeholder engagement and representation in Canada's PA system. Given a generational opportunity and high-level interest in expansion of protected areas in Canada and elsewhere, it is evident that as a diverse number of stakeholders and rights holders collaboratively map current and future land uses onto forest landscapes, science-based conservation targets and spatial prioritizations can inform this process.
\end{abstract}

Keywords: conservation; biodiversity; ecosystems; IUCN; land use; protected areas

\section{Introduction}

Given population growth and increasing pressures on land for human use [1], there is an increasing global reliance on protected areas (PAs) as cornerstones of conservation strategies. This global emphasis on PAs is evidenced by the widespread support for the Convention on Biological Diversity (CBD: an international treaty with 193 member countries) which, among other decisions, adopted the Aichi Biodiversity Target to protect $17 \%$ of the most biodiverse landscapes by 2020 [2]. The establishment of national PA systems has been the globally preferred approach to biodiversity conservation in the 20th and 21st centuries. National PA systems around the world have rapidly increased from 141 areas covering less than 1\% of Earth's land area in 1911 to 130,709 areas and 13\% global land coverage in 2011 [3,4] and 14.8\% in 2016 [5]. Furthermore, the rate of PA expansion has been growing: protected areas have increased nearly 80\% from 1990 levels. Coordination of PAs worldwide has been greatly facilitated by The World Commission on Protected Areas, administered by 
the International Union for Conservation of Nature (IUCN), which provides the following definition for a protected area:

"A protected area is a clearly defined geographical space, recognised, dedicated, and managed, through legal or other effective means, to achieve the long-term conservation of nature with associated ecosystem services and cultural values" [6].

This definition encompasses a variety of types of PAs, classified by management objectives [7] and most recently by governance type [8]. One of the current challenges for many developed nations is to pursue strategic expansion of their PA systems through diversification of management and governance mechanisms [9].

As of 2016, Canada has achieved protection of approximately $10.5 \%$ of its terrestrial and inland water area [5] (Table 1). More than $85 \%$ of Canada's PAs are classified as IUCN management categories I-IV [9], which prohibit industrial activities such as mining, forestry, and hydro development. Furthermore, much of the area protected exists in large PAs in excess of $3000 \mathrm{~km}^{2}$ [9]. Canada is one of the few nations with the potential to protect large, intact landscapes, particularly in the boreal and arctic regions that are expected to be under increasing pressures based upon a number of future climate change projections $[10,11]$. Ultimately, a key factor in the ability of Canadian PA systems to protect their biological resources is the sustained ecological integrity of the individual PAs. Given the existing level and location of protection, combined with the fact that many additional areas are currently in de facto protection [12], Canada has an opportunity unique among developed nations for a fundamental expansion of high-value, nondegraded protected areas. Furthermore, there is a strong willingness for comprehensive conservation planning owing to recent multi-stakeholder cooperative agreements and increasing political will [13] and objectives reported in the Federal Sustainable Development Strategy to meet the $17 \%$ area target by 2020 ([14], p. 48) agreed to under the Convention on Biological Diversity and related Aichi target [2].

The goal of this research is to highlight opportunities and avenues for expanding Canada's terrestrial PA system. The areas protected by province and territory are summarized in Table 1, whereas the areas protected by federal agencies are summarized in Table 2. We motivate our work with a description of the national context for PAs in Canada and provide examples focused on Canada's nationally dominant (>550 Mha) and ecologically important boreal forests. We then provide relevant background on the science of conservation planning, the application of ecological concepts to PA selection and management, and the application of IUCN PA categories in Canada. We offer guidelines to present opportunities regarding the expansion of PA systems derived from both national and international examples. Finally, we present two hypothetical scenarios for doubling protection that build on the current mix of IUCN PA categories at national and ecozone scales.

\section{Background for Protected Areas in Canada}

Canada has a history of protected area designation, management, and governance with the establishment of its first national park (Banff) in 1885 and its first provincial park (Ontario's Algonquin) in 1893. The federal government established Parks Canada (then the Dominion Parks Branch) as the World's first government protected area organization, in 1911 [15]. National and provincial parks are the most common types of protected areas in Canada, yet within the boreal region alone there are more than 70 types of PAs [9] that play various cultural and ecological roles. The balance among the various PA roles has evolved over time from a recreational focus towards an ecological one. Concurrently, the source of the dominant threats to PAs has also changed from internal sources, such as heavy visitation rates, to external ones, including overdevelopment of the surrounding landscape, climate change, invasive species, and airborne pollution [16]. See Table 3 for an overview of IUCN management categories including codes, descriptions, and Canadian examples.

As Canada contemplates PA expansion, it is worth noting that relative to other nations, Canada has a disproportionately large level of PAs that are in strictly protected classes [9]. National parks (IUCN 
Level II, see Table 4) comprise $~ 48 \%$ of Canada's PAs by area [17], and the evolution of its park system policies provide supporting evidence of the shift toward an ecological focus on protection. The shift began with the 1964 comprehensive statement of national parks policy, whose main purpose was to clarify ambiguity in the National Parks Act originally passed in 1930. The policy shift asserted that the fundamental role of national parks was to be one of protection rather than use [15]. This principle of ecological integrity was subsequently legally formalized in an amendment to the National Parks Act in 1988. The first National Park System plan was approved in 1971 to guide park expansion under a more systems-based approach. The emphasis was to increase representation of the 39 natural regions of Canada within the park system. As a result, given that roughly three quarters of the area within the national park system was designated after 1971, the majority of the park system was delineated within a value system that emphasized ecological integrity and representativeness. The mosaic of the larger set of all Canadian protected areas is more complicated, however, with management and governance carried out by diverse federal, provincial, and territorial agencies (Figure 1; Table 1) as well as First Nations and private land owners (Table 2) [5].

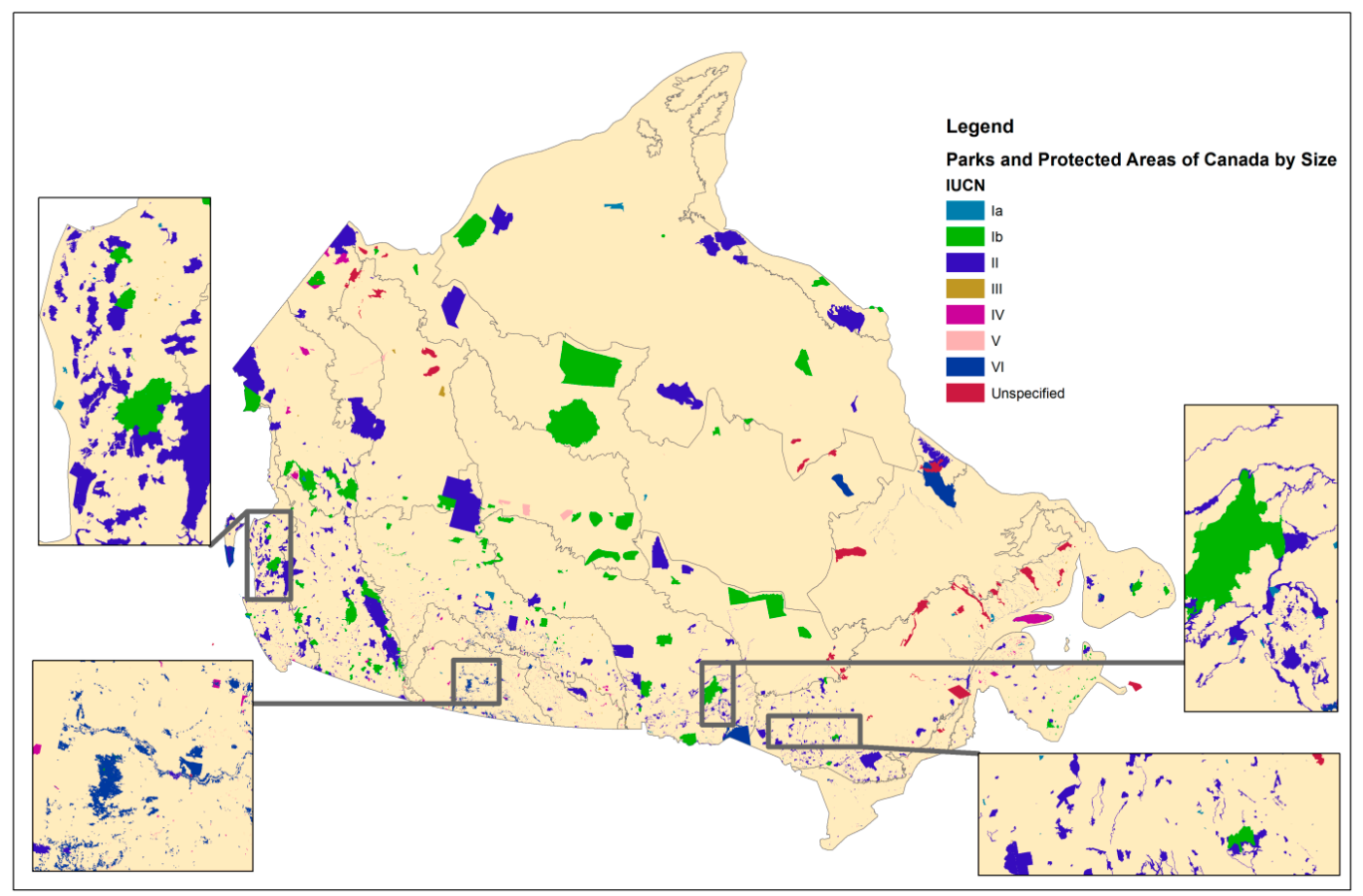

Figure 1. Map of Canadian protected areas and ecozones. Zoom views are provided of select areas to illustrate the context of smaller PAs. IUCN management categories are described in Table 3. Ecozones as described in [18] and labeled in Figure 2.

Canada's terrestrial PA system is poised for expansion for several complementary reasons: (1) to ensure representation and persistence of Canadian biodiversity; (2) to align with global protection levels and targets; and (3) to formalize the protection of de facto protected areas [12]. Recent studies have demonstrated the biases and underrepresentation of the current Canadian PA systems using a variety of biodiversity subsets and surrogates such as disturbance-sensitive mammals [19], species at risk [20], and productivity [21]. The disproportionate distribution to strictly protected IUCN categories shows an opportunity to employ some of the other IUCN classes, which would offer some flexibility in PA assignment, while remaining within international norms. As a consequence, many different jurisdictions are concurrently working to expand Canada's PA systems (e.g., [22]). Demonstrating an ongoing capacity for expansion, the total amount of protected area in Canada has more than doubled from $5.2 \%$ in 1990, to $10.5 \%$ in 2016 [5]. Many protected area management agencies have explicit expansion objectives. Nationally, Parks Canada is expanding with the objective of having at least 
one national park in each of Canada's 39 natural regions. There are currently 11 natural regions unrepresented in the national park system although some have interim protection [23]. Provincially, Ontario's Biodiversity Strategy sets a target to have $17 \%$ of terrestrial and aquatic ecosystems protected in line with the Aichi global target [2].

Table 1. Total percentage of terrestrial area protected by province and territory, Canada, 2016. Note that areas reported include land and freshwater, but not marine areas. Also note that not all jurisdictions in Canada report on protected areas that are privately owned.

\begin{tabular}{ccccc}
\hline Province or Territory & $\begin{array}{c}\text { Provincial or } \\
\text { Territorial Area } \\
\text { (Square } \\
\text { Kilometres) }\end{array}$ & $\begin{array}{c}\text { Area Protected } \\
\text { (Square } \\
\text { Kilometres) }\end{array}$ & $\begin{array}{c}\text { Percentage of } \\
\text { Province or } \\
\text { Territory Protected }\end{array}$ & $\begin{array}{c}\text { Percentage of total } \\
\text { National Area } \\
\text { under Protection }\end{array}$ \\
\hline British Columbia & 944,735 & 144,858 & 15.3 & 13.76 \\
Alberta & 661,848 & 83,140 & 12.6 & 7.90 \\
Nova Scotia & 55,284 & 6513 & 11.8 & 0.62 \\
Yukon & 482,443 & 56,334 & 11.7 & 5.35 \\
Manitoba & 647,797 & 71,139 & 11 & 6.76 \\
Ontario & $1,076,395$ & 114,470 & 10.6 & 10.87 \\
Nunavut & $2,093,190$ & 211,299 & 10 & 20.07 \\
Quebec & $1,512,418$ & 150,588 & 9.3 & 14.31 \\
Northwest Territories & $1,346,106$ & 125,657 & 8.5 & 11.94 \\
Saskatchewan & 651,036 & 55,654 & 7.3 & 5.29 \\
New Brunswick & 405,212 & 29,472 & 4.6 & 2.80 \\
Prince Edward Island & 72,908 & 3378 & 3.2 & 0.32 \\
\hline Totals & 5660 & 180 & & 0.02 \\
\hline
\end{tabular}

Table 2. Area protected by federal agency, Canada, 2016.

\begin{tabular}{ccc}
\hline Jurisdiction & $\begin{array}{c}\text { Terrestrial Area Protected } \\
\text { (Square Kilometres) }\end{array}$ & $\begin{array}{c}\text { Percentage of total National Area } \\
\text { under Protection }\end{array}$ \\
\hline Parks Canada & 338,964 & 32.2 \\
Environment and Climate Change Canada & 104,854 & 10.0 \\
Canadian Wildlife Service & 34,945 & 3.3 \\
Indigenous and Northern Affairs Canada & 0 & $<0.1$ \\
Fisheries and Oceans Canada & 462 & $<0.1$ \\
National Capital Commission & $-10,868$ & -1.0 \\
Correction for overlap among jurisdictions & 468,357 & 44.5 \\
Grand total & & \\
\hline
\end{tabular}

Note: Terrestrial areas include both land and freshwater. Entries represent the total area protected by each federal jurisdiction, accounting for any overlaps that may exist. This correction is made to avoid double-counting areas that benefit from more than one protection mechanism. No correction has been made for overlap between terrestrial and marine polygons resulting from variable definitions of coastlines or mapping artefacts. Areas under shared federal-provincial jurisdiction are included. Prairie Farm Rehabilitation Administration lands (Community Pastures) are being returned to provincial control and are no longer considered protected by a federal department. Source: Conservation Areas Reporting and Tracking System (CARTS) [24] (www.ccea.org/carts/).

\section{Application of IUCN Protected Area Management and Governance Types in Canada}

Societal values can be mapped onto the landscape as a continuum between market values and strict protection values [16]. The amount and configuration of these values on the landscape will affect the ecological, cultural, and economic potential of the landscape and will ultimately influence the future well-being of humans and of biodiversity. Different types of PAs give priority to different values; maintaining a mix of types on the landscape will thus help to achieve a balance among competing and complementary values. This will also contribute to more comprehensive and integrative conservation planning based on the principles of ecosystem management [25]. These principles emphasize the need to maintain ecosystems in the states required to achieve societal benefits while recognizing that ecosystems have some, albeit limited, resilience to natural and man-made stressors [26]. Diversified governance and management of PA types will be the key to success of planning and implementing landscapes with the right mix of values. Governance of different PA types involves decisions about 
PA objectives and strategies to achieve whereas management involves the actions required to achieve objectives [27].

\subsection{Classifying Protected Areas Based on Management Objectives}

Most PAs are established for a variety of reasons and with multiple management objectives. The IUCN management categories classify PAs based on their main management objectives (Table 3). A variety of objectives are acceptable within each category; therefore, there may even be variability amongst the management objectives of PAs within the same category. Importantly, the IUCN categories are based on the intentioned objectives. It is necessary to consider whether the area can realistically meet these objectives when assigning the area to a given IUCN category [28]. These categories facilitate international comparisons and some flexibility is required in their application [28]. Consistent application of the IUCN system by agencies that own and manage PAs in Canada is an achievable outcome, possibly guided by Canadian examples of interpretations of the IUCN system (e.g., Table 3) and the Canadian Council on Ecological Areas (CCEA) [28]. A few notable issues relevant to Canadian application of the IUCN categories are worth mentioning. Canada has large PAs in Categories I through IV, both in number and area, relative to other countries. Within these categories, some restricted human activities, which would otherwise be considered incompatible with these categories, are accommodated, such as small sections subject to extractive activities or First Nations traditional practices such as hunting and trapping. Traditionally, most areas that meet the criteria for Categories $\mathrm{V}$ and VI are beyond the scope of Canada's PA agencies [28]; however, this is not precluded and expected to develop as national and provincial PA systems continue to expand.

Regulations concerning the use of protected areas are not entirely consistent across international jurisdictions, nor are they consistent from province to province within Canada [29]. This presents challenges to categorizing and identifying the characteristics of PAs in Canada. For countries that are parties to the Convention on Biological Diversity, the IUCN has been instrumental in standardizing the reporting on PA systems by providing a typology of PAs consisting of six management categories [6,7]. Categories are not exclusive: many PAs have the characteristics of multiple IUCN categories, resulting in them being listed doubly or triply in existing PA databases. The CCEA produced guidelines for the application of the IUCN PA typology in Canadian PA systems [28]. Most recently, the IUCN provided a simplified typology of PAs consisting of four governance types [8]. This section provides a summary of these management and governance typologies with Canadian examples. It should be noted that this summary is not a replacement for the aforementioned publications and they remain the primary references. We also present an overview of the current representation of IUCN management categories in Canadian PAs. 
Table 3. IUCN management categories for protected areas with Canadian examples.

\begin{tabular}{|c|c|c|c|}
\hline $\begin{array}{l}\text { Management } \\
\text { Category }\end{array}$ & International Name * & Description & Canadian Example ** \\
\hline Ia & Strict Nature Reserve & $\begin{array}{l}\text { Areas subject to strict controls on human visitation, use, } \\
\text { and impacts for the conservation of biodiversity and } \\
\text { geological/geomorphological features;erve as important } \\
\text { references area for scientific research and monitoring. }\end{array}$ & $\begin{array}{l}\text { The terrestrial portion of Funk Island Ecological Reserve } \\
\text { (Newfoundland and Labrador) is primarily managed for } \\
\text { biodiversity and habitat conservation. Access is restricted to } \\
\text { people conducting approved scientific research. }\end{array}$ \\
\hline $\mathrm{Ib}$ & Wilderness Area & $\begin{array}{l}\text { Areas that are large and unmodified (or slightly modified) } \\
\text { protected and managed to retain their natural condition. }\end{array}$ & $\begin{array}{l}\text { Tobeatic Wilderness Area (Nova Scotia) primarily manages for } \\
\text { wilderness protection and maintenance of species/genetic } \\
\text { diversity. Its secondary management objective is low-impact } \\
\text { recreation and scientific research. }\end{array}$ \\
\hline II & National Park & $\begin{array}{l}\text { Areas that are large and natural (or near-natural) dedicated } \\
\text { to protecting large-scale ecological processes, characteristic } \\
\text { species and ecosystems, and offer visitor opportunities. }\end{array}$ & $\begin{array}{l}\text { Wood Buffalo National Park (Alberta) has many management } \\
\text { objectives including perseveration of species and genetic } \\
\text { diversity, recreation and tourism, scientific research, and } \\
\text { wilderness protection. }\end{array}$ \\
\hline III & Natural Monument & $\begin{array}{l}\text { Areas that protect specific natural monuments (e.g., caves) } \\
\text { or living features (e.g., ancient groves). These are often } \\
\text { smaller areas that receive many visitors due to high historic } \\
\text { or cultural value. }\end{array}$ & $\begin{array}{l}\text { The Nisutlin River National Wildlife Area (Yukon) has } \\
\text { management objectives that include protecting biodiversity } \\
\text { and habitats, maintaining traditional and current use of the } \\
\text { territory by Teslin Tlingit, and encouraging awareness through } \\
\text { public visitation. }\end{array}$ \\
\hline IV & $\begin{array}{l}\text { Species/Habitat } \\
\text { Management }\end{array}$ & $\begin{array}{l}\text { Areas devoted to species or habitat conservation, often } \\
\text { focusing on species or habitats of particular concern and } \\
\text { requiring active management interventions. }\end{array}$ & $\begin{array}{l}\text { Last Mountain Lake National Wildlife Area (Saskatchewan) } \\
\text { manages for protection of ecosystems and biodiversity. }\end{array}$ \\
\hline V & $\begin{array}{l}\text { Protected } \\
\text { Landscape/Seascape }\end{array}$ & $\begin{array}{l}\text { Areas with a distinct character and significant ecological } \\
\text { and cultural values resulting from the interaction of people } \\
\text { and nature over time. }\end{array}$ & $\begin{array}{l}\text { The National Capital Greenbelt (Ontario) is managed to protect } \\
\text { natural and cultural resources, provide opportunities for } \\
\text { recreation, and safeguard the working rural landscape. }\end{array}$ \\
\hline VI & $\begin{array}{l}\text { Protected areas with } \\
\text { Sustainable use of Natural } \\
\text { Resources }\end{array}$ & $\begin{array}{l}\text { Areas that are large and jointly conserve ecosystems, } \\
\text { habitats, cultural values, and traditional natural resource } \\
\text { management systems. The majority of the area should be in } \\
\text { a natural condition and the reminder under sustainable } \\
\text { natural resource management. }\end{array}$ & $\begin{array}{l}\text { Churn Creek Protected Area (British Columbia) is managed for } \\
\text { the preservation of natural and cultural features, tourism and } \\
\text { recreation, maintenance of cultural and traditional attributes, } \\
\text { and sustainable resource use. }\end{array}$ \\
\hline
\end{tabular}

* International name does not necessarily correspond with Canadian usage of the same term. For example, Cypress Hills Interprovincial Park is classified as Category II National Park. ** Canadian examples were taken from CCEA [28] except for Category V which came from Swinnerton and Buggey [30]. Source: Adapted from IUCN [7]. 
Table 4. Protected areas (PAs) in Canada, by IUCN class.

\begin{tabular}{cccc}
\hline $\begin{array}{c}\text { IUCN Management } \\
\text { Category }\end{array}$ & IUCN International Name & $\begin{array}{c}\text { Percentage of total } \\
\text { National Area } \\
\text { under Protection }\end{array}$ & $\begin{array}{c}\text { Percentage of total } \\
\text { National Area }\end{array}$ \\
\hline Ia & Strict Nature Reserve & 1.0 & 0.1 \\
Ib & Wilderness Area & 33.2 & 3.5 \\
II & National Park & 48.8 & 5.1 \\
III & Natural Monument & 0.2 & $<0.1$ \\
IV & Species/Habitat Management & 2.0 & 0.2 \\
V & Protected & 0.4 & $<0.1$ \\
Landscape/Seascape & Protected Area with & 1.5 \\
Total & Sustainable Use of Natural & Resources & 10.4 \\
\hline
\end{tabular}

\subsection{Classifying Protected Areas Based on Governance Types}

Governance can be defined as "the interactions among structures, processes, and traditions that determine how power and responsibilities are exercised, how decisions are taken and how citizens or other stakeholders have their say" [31]. Governance is carried out by actors (rights holders and stakeholders) that hold power, authority, and responsibility and are accountable for meeting the protection objectives of PAs (Tables 1 and 2) The purpose of the IUCN governance classification system is to create a standardized framework in which all governance of PAs and PA systems can be assessed, compared, evaluated, and improved. In addition to the type of governance of a PA (Table 5), the quality of governance can also be assessed to the extent of how closely governance principles are followed in the process of making actual decisions. PA governance also concerns de facto decision makers that affect the conservation objectives of the PAs through informal means [8]. For example, ongoing enforcement shortcomings may result in illegal development and commercial exploitation in PAs by members of the public, such as cattle grazing and wood harvesting [32]. Parks Canada has aimed to demonstrate international leadership in establishing the principles of good governance of PAs [31]. In Table 5, we also offer Canadian examples of each category. We present these examples of governance types in Canadian PAs as a stimulus for future discussions on Canadian interpretation of the IUCN PA governance framework. 
Table 5. IUCN governance categories for protected areas with Canadian examples ** (adapted from IUCN [8]).

\begin{tabular}{|c|c|c|c|}
\hline Category & International Name & Description & Sub-types/Authority with Canadian Examples [ ] \\
\hline A & $\begin{array}{l}\text { Governance by } \\
\text { government }\end{array}$ & $\begin{array}{l}\text { One or more government bodies holds authority, } \\
\text { responsibility, and management accountability. Alternately, } \\
\text { planning and/or daily management tasks may be } \\
\text { delegated to other actors. }\end{array}$ & $\begin{array}{l}\text { - Federal or national ministry or agency [The majority of Canada's national Park System is } \\
\text { managed by Parks Canada *] } \\
\text { - Sub-national ministry or agency [Algonquin Park (Ontario) is managed by Ontario Parks.] } \\
\text { - Government delegated manager [Quebec's Zones d'exploitation contrôlée (ZEC) are } \\
\text { hunting grounds located on public lands but management and conservation is carried out } \\
\text { by an NGO.] }\end{array}$ \\
\hline B & Shared governance & $\begin{array}{l}\text { Several actors formally and /or informally share authority } \\
\text { using institutional mechanisms and processes. }\end{array}$ & $\begin{array}{l}\text { - One or more sovereign State or Territories governing Transboundary PA [Canada and the } \\
\text { United States formed Waterton-Glacier International Peace Park by the merger of the Water } \\
\text { lakes and Glacier National Parks in 1932.] } \\
\text { Diverse actors and institutions working in collaborative governance [Cypress Hills } \\
\text { Interprovincial park (Alberta, Saskatchewan)] } \\
\text { Pluralist board or other multi-party governing boding working in joint governance. } \\
\text { [The Gwaii Haanas Agreement is a cooperative agreement between the Haida Nation and } \\
\text { the Government of Canada for the governance of the Gwaii National Marine Conservation } \\
\text { Area Reserve (British Columbia).] }\end{array}$ \\
\hline $\mathrm{C}$ & Private governance & $\begin{array}{l}\text { Land owner retains authority for managing PA subject to } \\
\text { government legislation and restrictions. Government } \\
\text { recognition of land owner's authority is required to } \\
\text { ensure accountability. }\end{array}$ & $\begin{array}{l}\text { - Individual land owners [Quebec's Natural Heritage Conservation Act allows the Minister } \\
\text { of Sustainable Development, Environment, Wildfire and Parks to recognize private } \\
\text { properties as nature reserves.] } \\
\text { - Non-profit organizations [Gault Nature Reserve (Quebec) is owned by McGill University.] } \\
\text { - For-profit organizations [Haliburton Forest and Wild Life Reserve Ltd. (Ontario) is a } 300 \\
\text { km2 privately owned forest near Algonquin Provincial Park managed for conservation, } \\
\text { tourism, and timber.] }\end{array}$ \\
\hline $\mathrm{D}$ & $\begin{array}{l}\text { Governance by } \\
\text { indigenous people } \\
\text { and local communities }\end{array}$ & $\begin{array}{l}\text { Indigenous peoples and/or local communities hold } \\
\text { management authority and responsibility through various } \\
\text { forms of customary or legal institutions and rules. }\end{array}$ & $\begin{array}{l}\text { - Indiginous peoples [Tla-o-qui-hat Tribal parks (British Columbia) are watersheds managed } \\
\text { by Tla-o-qui-aht First Nations to integrate human and ecosystem well-being.] } \\
\text { - Local communities [We are unaware of any examples of this sub-type at the present time.] }\end{array}$ \\
\hline
\end{tabular}

* Thirteen National Parks are governed collaboratively (Category B) through cooperative management boards between Parks Canada and the First Nations on whose territories the parks are located. ${ }^{* *}$ Canadian examples are our own interpretations of the IUCN governance categories in the Canadian context with the exception of the Gwaii national Marine Conservation Area, which was presented as an example of Category B in IUCN Governance of Protected Areas [8]. 


\subsection{Distribution of IUCN Management Categories within Canada's Protected Areas}

The proportion of Canada's protected area in each IUCN category shows an uneven distribution, skewed towards categories with the strongest restrictions to human activities within them (Figure 2; Table 4). Approximately $82 \%$ of all Canada's protected area is classified as Categories Ib and II and less than 3\% in Categories III and IV (Table 4). By definition, PAs in Categories Ib and II are large natural areas (e.g., national parks and wilderness reserves), and given the remote nature of much of Canada, it is perhaps not surprising that they make up a large percentage of the overall area protected. Conversely, PAs in Categories III and IV are usually small areas, because of their focus on protection of particular features (III) or requirement for active management interventions (IV). Hence, Canada's current division of protected area among these categories is in line with expectations given Canada's history, settlement patterns, and geography. However, there is little reason that Categories Ia, V, and VI should not have greater representation as they also require large areas to meet their management objectives (especially Categories Ia and VI).

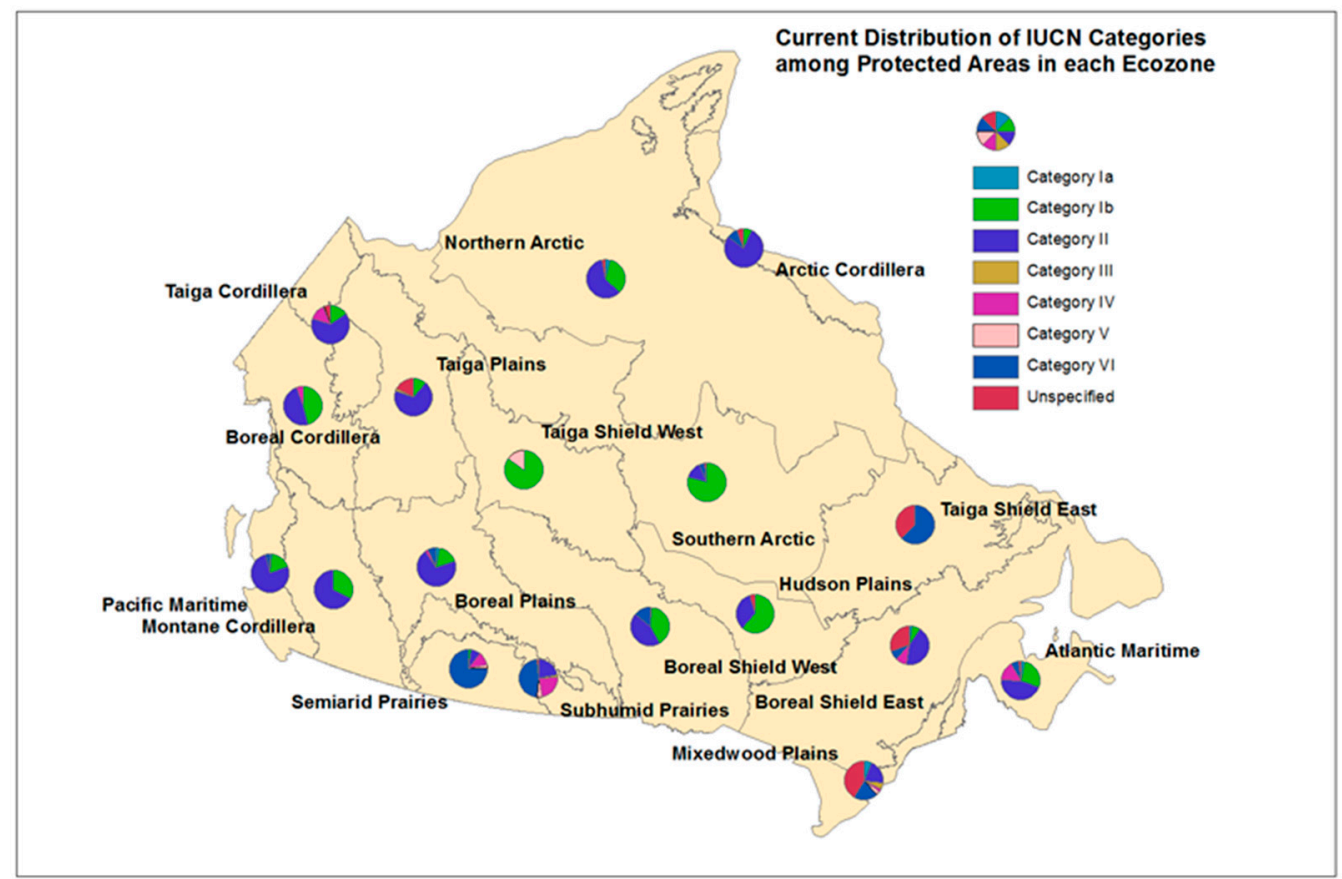

Figure 2. National map of ecozones with pie charts individually illustrating the breakdown of protected areas by ecozone into IUCN categories. Note: Ecozones differ with respect to the total amount of area protected (see Figure 3) [24].

The spatial distribution of Canada's protected areas is noteworthy for its spatial unevenness. The size of PAs in all IUCN categories generally increases from east to west and from north to south. Hence, the ecozones of Canada have considerably differing amounts, proportions, and patterns of protection, ranging from the smallest amount of area in the southern Mixedwood Plains to the highest in the Southern Arctic. Furthermore, no one category is uniformly dispersed, for example, Categories $\mathrm{Ib}$ and II are less abundant in the eastern ecozones (Taiga Shield East and Boreal Shield East). Only four of the eighteen ecozones have PAs in all categories and only Category II is present in all ecozones (Figure 2; Table 4), meaning that no single ecozone closely represents the national pattern. It could be expected that some PA categories would be less well-suited to some ecozones than others; for example, Category I PAs that are large wilderness areas would be difficult to establish in the populated Mixedwood Plains ecozone. Nevertheless, it would seem that managers could work at the ecozone scale to better diversify and/or rebalance PAs in light of neighboring ecozones or the national average. 


\section{Context for Expanding Canada's Protected Area in Forested Ecosystems}

Globally, terrestrial PAs have increased from covering just 3.45\% of land surfaces in 1985 [33] to $13 \%$ in 2010 [34]. This expansion has been achieved through a variety of political, legal, and other effective avenues. Given the current extent of de facto protected areas [12], Canada has an opportunity to pursue many of these avenues to improve protection in its forested ecosystems. In this section, we discuss models of PA management and governance that involve a broad range of rights holders and stakeholders. We first provide international examples of how these approaches can be useful in PA system expansion in general and follow up with IUCN categories to target for PA expansion in Canada's forested ecosystems. We acknowledge that conservation contexts will vary among forested ecozones and what may be achievable in one ecozone, or subregion, may not apply elsewhere due to factors such as industrial allocations, land ownership patterns, and the evolving status of Aboriginal and Treaty rights and land use planning exercises [35].

\subsection{Recent International Precedents for Expansion of Protected Areas}

Many nations have made commitments to expand terrestrial protected area systems, however progress has been limited [4]. For example, in 2004 over $80 \%$ of nations had signed the CBD, thereby committing to protect a portion of all of their ecoregions [36]. As of 2009, less than half of the terrestrial ecoregions had met the target of protecting $10 \%$ of each ecoregion by 2010 [4]. Furthermore, only $33 \%$ of terrestrial ecoregions have met the more recent target of $17 \%$ protection by 2020 [34]. At present, almost all nations have signed on to the CBD, with the exception of the USA who have signed but not ratified the treaty ${ }^{1}$. Some international examples of recent increases to PA systems are of particular interest, as these offer possible new opportunities or ways of understanding PA expansion. In Table 6, we share a few representative international case studies of PA expansion of relevance to Canadian conditions (Australia and Finland) and other innovative international examples that incorporate climate change adaptation and community participation (South America).

Australian researchers have been active in conservation biology and biodiversity science for the past two decades [37]. Examples of recent innovations include (1) costing the expansion of PA systems [38] and (2) optimizing the allocation of resources between protecting intact habitats versus restoring degraded habitats in order to best facilitate the persistence of threatened species under climate change [39]. Australia's terrestrial PA systems are noteworthy because of the large portion which is jointly managed with Indigenous peoples. Indigenous Protected Areas (IPAs) are defined by the Australian Government as areas:

"of land and/or sea over which the Indigenous traditional owners or custodians have entered into a voluntary agreement with the Australia Government for the purposes of promoting biodiversity and cultural resource conservation." [40]

IPAs made up 30\% of Australia's total area protected in 2012 [41]. The IPA designation was formally recognized in 1997, and has expanded rapidly such that by 2011 there were 48 declared IPAs and another 40 IPA Consultation Projects underway [42]. In theory, IPAs may qualify as any one of the seven IUCN management categories ranging from most to least natural conditions within PAs. In practice, many IPAs have nominated more than one IUCN category. The majority of IPAs are assigned to Categories V (16 IPAs) and VI (31 IPAs) incorporating human-nature interactions and sustainable resource use, respectively [42]. The remainder are assigned to Categories VI (11 IPAs), III (6 IPAs), and II (7 IPAs). IPAs have proven an effective avenue for recent and future growth of the Australian PA system [43].

Colombia, Ecuador, and Peru are three of seventeen mega-diverse countries identified by Conservation International and collectively comprise the majority of the Tropical Andes-a biodiversity

1 https://www.cbd.int/information/parties.shtml (accessed on 19 October 2018). 
hotspot with an exceptionally high concentration of endemic species [44]. These three countries are contiguous and adjacent with shared borders and interconnected habitats and ecosystems. Their respective national PA systems have all undergone rapid, recent expansions within their specific political, legal, and institutional contexts. They have launched a novel initiative to coordinate a collective learning process to develop strategies for climate change adaptation across their PA systems [45].

Finland, like Australia, has been innovative in systematic conservation planning and spatial conservation prioritization [46]. Recently, Finnish scientists have developed methods to optimize the expansion of PA systems by identifying areas that, if protected, would add the most complementary conservation value to existing PAs [47]. This acknowledges the reality of most conservation planning efforts which cannot ignore existing land use patterns and therefore must account for previous limitations, land use plans and existing protected areas in spatial conservation prioritizations (see a past paper [48] for a Canadian example).

Table 6. International examples of protected area system expansion.

\begin{tabular}{|c|c|c|c|}
\hline Country & $\begin{array}{l}\text { Percentage of } \\
\text { Protected } \\
\text { Terrestrial Area } \\
\text { in } 2012 \\
\end{array}$ & $\begin{array}{c}\text { Increase in } \\
\text { Percentage of } \\
\text { Protected Area from } \\
1990 \text { to } 2012 \\
\end{array}$ & Lessons Learned \\
\hline Australia & 12.85 & 5.74 & $\begin{array}{l}\text { - Ability to subdivide private lands will greatly influence costs } \\
\text { of PA expansion and may result in protection of some lands } \\
\text { with lower conservation value [38]. } \\
\text { - Habitat protection is the primary action required to maintain } \\
\text { threatened species with reference to climate change, although } \\
\text { restoration plays an important role for some species and } \\
\text { locations [39]. } \\
\text { - Comanagement of PAs with Indigenous groups, NGOs, } \\
\text { and business organization should adapt based on ongoing } \\
\text { evaluation of comanagement [43]. }\end{array}$ \\
\hline $\begin{array}{c}\text { Columbia, } \\
\text { Ecuador, Peru }\end{array}$ & $21.18,23.73,19.06$ & $1.89,1.88,14.33$ & $\begin{array}{l}\text { - Transnational coordination of PA systems can improve the } \\
\text { effectiveness of PA systems as they respond to climate change. } \\
\text { Participatory zoning can integrate local people into PA } \\
\text { management [49]. } \\
\text { - Comanaged public, private, and community-based PAs need } \\
\text { management plans that define cooperation, coordination } \\
\text { and participation frameworks for PAs and related buffer } \\
\text { zones [50]. }\end{array}$ \\
\hline Finland & 15.10 & 10.73 & $\begin{array}{l}\text { - Spatial conservation priorities need to account for the quality } \\
\text { and connectivity of existing PAs [47]. } \\
\text { The majority of high-quality, unprotected forests (in southern } \\
\text { Finland) are on privately owned lands [47]. } \\
\text { - Flexible, voluntary-based conservation agreements facilitate } \\
\text { the recognition of private PAs by government PA agencies. } \\
\text { Inverse spatial conservation prioritization can minimize the } \\
\text { negative ecological effects of extractive resource use [51]. }\end{array}$ \\
\hline
\end{tabular}

\subsection{Expansion through Recognition of New IUCN Management Categories and Governance Types}

As illustrated by the aforementioned international case studies, diversifying management and governance types represented in the PA systems can expedite and facilitate expansion [31]. There many ways that management and governance diversification can benefit PA system expansion [8]:

- meeting expansion area targets faster by incorporating into official PA systems de facto protected areas and areas governed by indigenous peoples, the private sector, or shared governance;

- building connectivity in PA networks by adding stepping stones and corridors that are not publicly owned lands;

- improving the representativeness and adequacy of PA systems particularly in countries with a large proportion of private ownership; and

- increasing the number of people involved in conservation which may lead to social acceptance and sustainability of the system. 
The success of a diversified PA system will hinge on ensuring that all types of PAs prioritize the long-term conservation of biodiversity based on the ecological principles outlined earlier.

Combinations of IUCN management and governance categories can be expanded into an IUCN Protected Area Matrix (see Table 7). Such a matrix helps to visualize and classify the diversity of PA types that can currently occur in a PA system [8]. It can also be used to consider options for expanding the PA system and for communicating these options to PA agencies and stakeholders. For example, this management-governance matrix could assist in the development of a management framework by filling in all applicable rows of a single column as though they represent nested management arrangements within a single PA or PA system. Nested within a national park, it is possible to define a species management area for a vulnerable species [23] or allocate land for sustainable resource use [49]. There is also a current IUCN adaptation possibility, akin to that of the USA, whereby US National Forests are classified as IUCN Category VI protected areas (Managed Resource Protected Area $^{2}$ ). This allows for some forest harvesting, but not comprehensive industrial activity.

Based upon IUCN literature [8] and our understanding of management and governance types, shaded cells in the matrix highlight potential categories that could contribute to the expansion of Canada's PA system. These are presented as options for consideration, but not necessarily as exhaustive. The "Governance by indigenous peoples" column is highlighted as an ongoing avenue for expansion. Parks Canada is already recognizing the important governance role of aboriginal communities in a variety of PA types either autonomously or through shared governance. The one national park created in 2012-2013 was Nááts'ihch'oh National Park Reserve in the Northwest Territories [23]. Aboriginal communities have developed comprehensive land-use plans that balance cultural and ecological values with opportunities for long-term economic development such as the Tla-o-qui-hat Tribal Parks (coastal British Columbia).

Another key opportunity for expansion highlighted in Table 7 is "Private governance", informed by the South American and Finnish examples noted earlier. Indeed many more countries have identified private lands as priority areas for PA expansion including the United States, Paraguay, Costa Rica, Bolivia, South Africa, and New Zealand summarized in IUCN [8] and in Jackson and Gaston [52]. They are thought to have the potential to improve the representativeness and connectivity of PA systems [53,54]. However, in Great Britain where PAs are not constrained to public lands (more than half of all PAs are on private lands), there is still biased representation of biodiversity surrogates within the PA system [52]. Biodiversity conservation on private lands may be improved by diversifying landowner engagement strategies beyond the two most common conservation tools: conservation easements and direct payment programs [55]. Current research is focussed on identifying when different conservation tools are most likely to be effective across diverse private lands (e.g., based on ecological dynamics and interactions between individual landholders [56]). More research is needed into the circumstances under which private PAs should be incorporated into national PA systems [8,57].

2 http://www.iucn.org/about/work/programmes/gpap_home/gpap_quality/gpap_pacategories/gpap_category6. 
Table 7. IUCN Protected Area Matrix. Light grey cells indicate key opportunities for expansion of Canada's PA systems. Source: Adapted from IUCN [8].

\begin{tabular}{|c|c|c|c|c|c|c|c|c|c|c|c|c|}
\hline & & & & & & Gover & ance Cate & gory & & & & \\
\hline & & $\begin{array}{l}\text { A. } \\
\text { by }\end{array}$ & $\begin{array}{l}\text { yer } \\
\text { er }\end{array}$ & & B. Sh & red Go & rnance & $\begin{array}{c}\text { C. } \\
\text { Go }\end{array}$ & $\begin{array}{l}\text { Priva } \\
\text { verna }\end{array}$ & $\begin{array}{l}\text { te } \\
\text { ince }\end{array}$ & $\begin{array}{l}\text { D. G } \\
\text { by I } \\
\text { Peopl } \\
\text { Con }\end{array}$ & $\begin{array}{l}\text { ance } \\
\text { nous } \\
\text { Local } \\
\text { ities }\end{array}$ \\
\hline & & 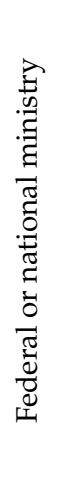 & 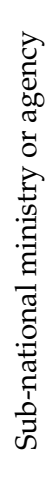 & 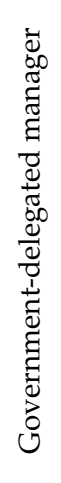 & 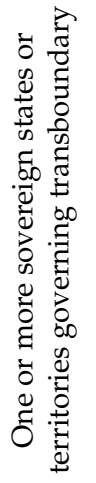 & 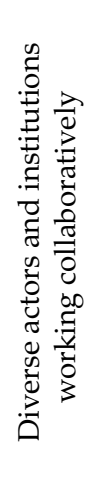 & 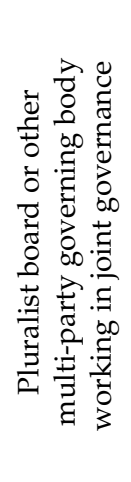 & 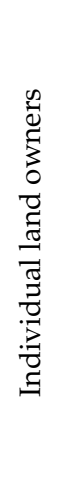 & 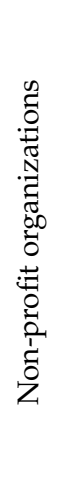 & 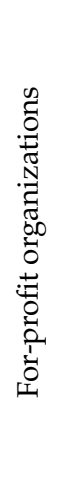 & 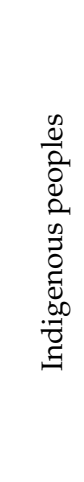 & 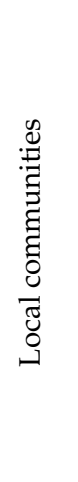 \\
\hline \multirow{7}{*}{ 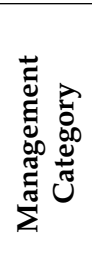 } & \multicolumn{12}{|l|}{ Ia } \\
\hline & \multicolumn{12}{|l|}{$\mathrm{Ib}$} \\
\hline & \multicolumn{12}{|l|}{ II } \\
\hline & \multicolumn{12}{|l|}{ III } \\
\hline & \multicolumn{12}{|c|}{ IV } \\
\hline & \multicolumn{12}{|l|}{$\mathbf{V}$} \\
\hline & \multicolumn{12}{|l|}{ VI } \\
\hline
\end{tabular}

\subsection{Spatial Conservation Planning Opportunities to Enhance Canadian PA Systems}

As a large nation with extensive areas with little access or development [12], Canada has globally unique opportunities for using and implementing spatial conservation planning [9]. Powers et al. [48] reviewed scenarios for integrating accessibility and intactness into conservation planning in Canada, using the boreal forest region to illustrate how biological elements, costs, and size considerations can provide analytical criteria for implementation of spatial conservation planning scenarios and to inform prioritization. Beyond criteria-based spatial conservation planning, Powers et al. [58] conducted analyses to incorporate climate change projections and related impact upon vegetation into a Canadian boreal conservation assessment. Similarly, remote sensing and model-derived biodiversity indicators [59] were utilized by Holmes et al. [60] to show that climate change will alter the future vegetation characteristics expected in British Columbia, impacting the nature of protection offer by PA. Spatial data sets, especially those from remote sensing, offer unique opportunities for understanding not only landscape status and protection status but understanding what spatial differences in physical environments relate to biodiversity [61]. In general, these studies show that there is available information and methodological options to inform spatial conservation planning in Canada.

Building upon the above insights and practical considerations, there are a number of strategies/pathways to increase representation and effectiveness goals for PA systems in Canada. We outline here some opportunities with Canadian examples where possible.

Privately conserved areas are increasingly being recognized as a legitimate and effective governance type. They can play a role in increasing the representativeness and connectivity of PA systems, while at the same time engaging actors other than government, which increases conservation awareness and engagement, and ensures the long-term sustainability of the PA system. Examples of this PA type already exist in Canada. The province of Quebec is an example for incorporating private sector actors and NGOs in PA management. In Ontario, Oak Ridges Moraine land-use planning process has protected long, wide corridors on private lands through negotiations between government, NGOs, and the private sector [62]. 
De facto protected areas [12] could be brought into formal PA systems. To meet IUCN constraints, these areas would have to be primarily managed for nature conservation with up to $25 \%$ managed for other compatible reasons, such as sustainable resource use [6]. Given that constraint, not all de facto protected areas could qualify as PAs, but could be considered as "other effective area-based conservation measures" [8]. For example, where conservation is an indirect outcome of other management goals, the area would not meet the IUCN PA definition. More northerly regions may readily meet IUCN PA definitional requirements, with more southerly areas subject to sustainable forest management requiring additional investigation. Of note, Canada has more than 167 Mha of managed forest lands under third party forest certification [63], with ecological considerations, via provision of ecosystem services, included as an element of certification.

Zoning within and around PAs could enhance rather than expand the current PA system by improving its ecological integrity. Zoning within PAs could increase representation of different IUCN categories by creating strong protection zones within lower-level PAs and vice versa. For example, Algonquin Provincial Park has strong protection zoning for $12.6 \%$ of the total park area in the form of Natural Environment, Nature Reserve, Wilderness, or Historical zones. Another $65.3 \%$ of the total park area is zoned as Recreation/Utilization and includes a sustainable forest industry [64]. Another example of PA's with multiple levels of protection is the UNESCO Biosphere reserve designation, of which there are currently 13 in Canada. Zoning around PAs provides a means to balance conservation and development across broader spatial scales and among diverse stakeholders and rights holders [65]. Creating buffer or multiple-use transition zones can help maintain the ecological integrity of PAs [13]. Zoning for ecological corridors through developed areas will also be important to allow species to move among PAs to meet their resource requirements or to track suitable habitat as the climate changes.

\section{Expansion Scenarios for Canada's Protected Area Systems: An Example in the Boreal}

The protected area targets suggested specifically for Canada range from $12 \%$ [66,67], to $20 \%$ [68], to $50 \%$ [69]. Canada's PAs are neither balanced in terms of total amount protected, proportion protected, nor balance among IUCN types. For the boreal region specifically, the balance among IUCN types differs substantially across the ecozones (Figure 3b). Two notably large and underprotected ecozones are Boreal Shield East and Taiga Shield East, which currently protect $7 \%$ and $3 \%$ of their large areas respectively. Expansion to the current $17 \%$ federal target [14] in these ecozones is made possible by the de facto opportunities for protection in the boreal relative to the more heavily populated areas further south [12,48], which may have more restrictive pre-existing land-use commitments [9]. The $17 \%$ scenario currently under consideration represents more than a doubling of the $8 \%$ of the boreal currently under protection (Figure 3a).

Due to political, economic, and social factors that are a necessary part of conservation in practice, there are circumstances in which a government may be limited in its ability to employ systematic, quantitative methods for identifying areas for protection. In those cases, governments may consider other approaches to guide the expansion of PA systems. Two potential approaches (among many) towards expanding Canada's protected areas would involve (i) expanding the area of existing IUCN categories or (ii) expanding the range of IUCN categories within the PA system (while also increasing the area under protection). The first approach would maintain the same types of IUCN categories that are currently found within each ecozone, and focus on expanding the areas represented by each of these categories. For the boreal example, this would result in more IUCN category Ib (wilderness areas) and II (national parks), as these are currently the most prevalent IUCN categories currently found in the boreal. An alternative approach would be to broaden the range of IUCN categories that are currently represented in each ecozone, thereby introducing new models of protection that are tailored to regional conditions. 
(a)

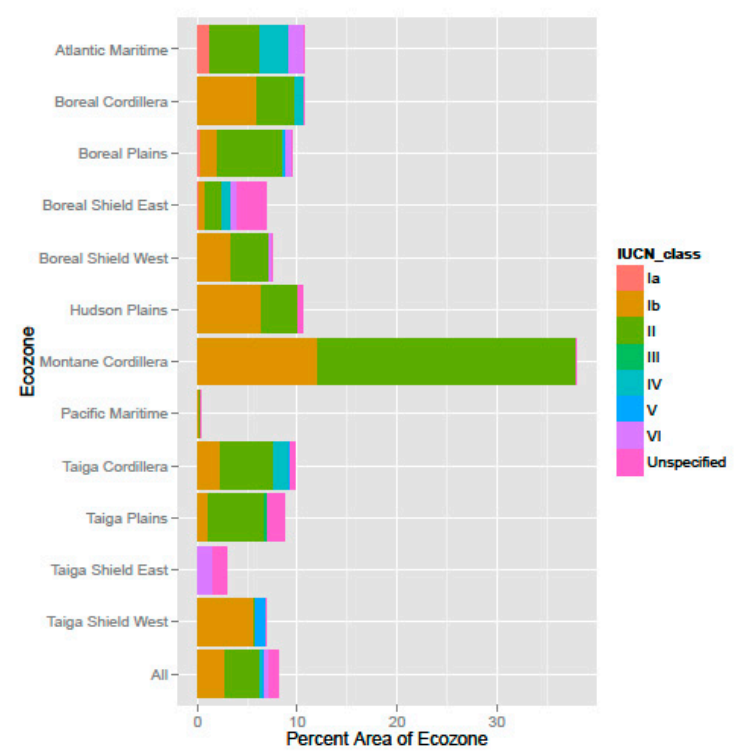

(b)

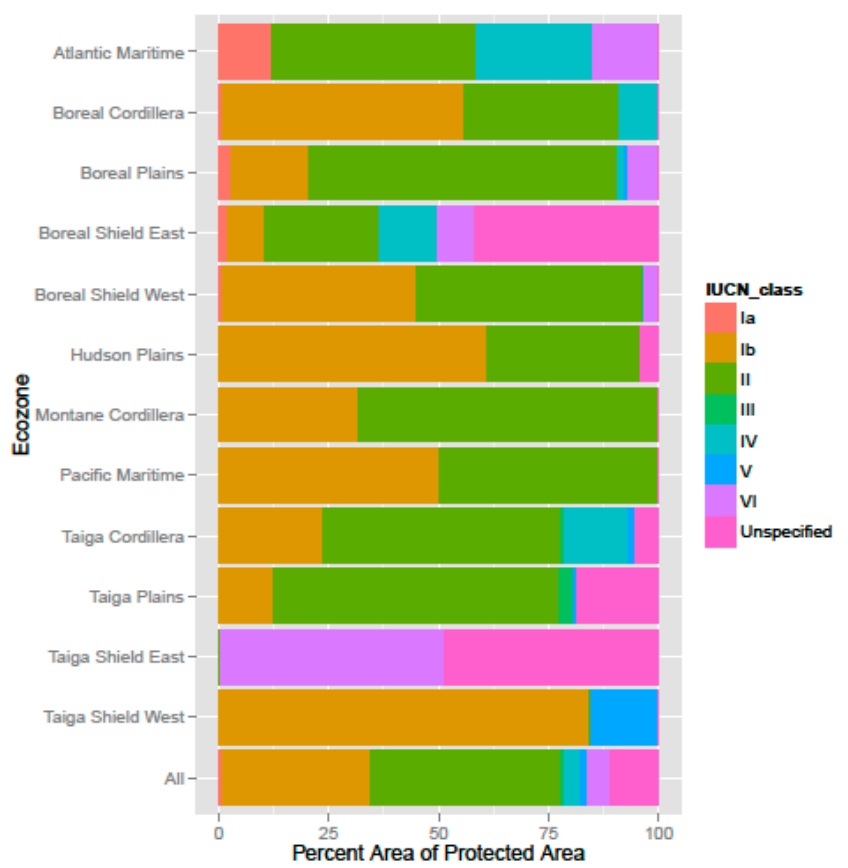

Figure 3. IUCN management categories for PAs in boreal ecozones, aiming to show balance among IUCN types. The stacked bar for each ecozone shows (a) the proportion by total amount of protected area found in each boreal ecozone ([9] and (b) the proportion by amount of protected area in each ecozone.

\section{Opportunities and Conclusions}

Currently, PA systems in Canada are dominated by relatively large PAs with strict protection in comparison with other countries. This is especially true for protection in Canada's forested ecosystems where Categories Ib and II make up $80 \%$ of all PAs and 34 PAs are larger than $3000 \mathrm{~km}^{2}$ [9]. Nonetheless, only a small fraction of PAs in Canada meet the size requirements to maintain minimum viable populations of large, wide-ranging mammals or to protect landscape dynamics and natural disturbance regimes [9]. A resilient PA network consists of multiple types of PAs including a system of representative core areas, corridors, stepping stones, and buffers. In this research, we posit that strategic expansion of protection in Canada could benefit from diversification of PA types to make greater use of less restrictive PA types (IUCN Categories V and VI). This would extend biodiversity conservation values across the landscape while strengthening connections among existing PAs. We encourage an 
ongoing dialogue about PA system diversification by providing Canadian interpretations of IUCN management and governance categories for PAs along with Canadian and international examples of their application. Towards this goal, our synthesis of the literature and current context in Canada indicated the following opportunities.

\section{Canadian interpretation and implementation of IPA}

International examples of IPA offer insights for implementation in Canada. National circumstances inform the nature of governance possible from IPA. For instance, agreements between Indigenous traditional owners or custodians in Australia have resulted in voluntary stewardship agreements that now result in $30 \%$ of national PA. The IPA designation is relatively new, with formal recognition in 1997, leaving opportunities for definition and implementation in a Canadian context. IPA can be created over a number of IUCN categories, although most frequently those (e.g., Categories V, VI) that allow for some human-nature interaction or sustainable resource use.

\section{Identify and augment private PAs}

An important next step to inform PA system diversification will be to identify opportunities for private PAs. We propose mapping privately owned lands within de facto PAs [12] to determine candidate private PAs. As a second step, the map of candidate PAs should be assessed for their complementarity to the existing PA portfolio [47], particularly within its ecozone. This assessment would be based on the degree to which candidate PAs contribute to the representativeness and effectiveness of the PA system and their degree of irreplaceability. Private lands offer opportunities for PA expansion through provision of habitat and harbors for endangered or threatened species [70]. Knowledge of the ecological contribution of private lands can be combined with cultural, economic, and sociopolitical considerations to designate new PAs.

\section{Clarify IUCN categories of PAs}

Reporting IUCN categories for PAs is particularly challenging because the data is dispersed across the different governing agencies, noting that there are guidebooks to help standardize the assignment of IUCN categories [6,28]. However, despite best efforts, the present assignment of protected areas to IUCN categories globally does not correspond to the expected gradient of naturalness [29]. The management and governance categories discussed herein can help to enhance biodiversity representation and persistence by identifying balanced solutions when working with diverse rights holders and stakeholders, as well as considering formalizing protection of large, de facto PAs. Future work will also require assigning PAs to governing categories that may prove even more challenging since PA governance may be subject to change over time.

\section{Value connectivity in PA assessments}

Maintaining and enhancing the connectivity of protected landscapes will be critical as climatic change redistributes species habitats [71] and alters the frequency, extent, and intensity of disturbances [72]. This may be especially (though not exclusively) relevant in boreal regions, where disturbances can be large and contiguous [73]. For species to respond to climate-induced changes and maintain viable populations, PA systems must be conscious of the evolutionary continuum [74] and designed to allow for broad-scale traversability of the landscape. Improving the connectivity among PAs is a way to increase the persistence of biodiversity across the network of PAs. Recent work across large areas, including with Zonation $[47,75]$ and circuit theory [76-78] point toward spatial data informed decision support tools that explicitly consider a variety of measures of connectivity.

\section{Consider tradeoffs}

Systematic conservation planning [79] will require the a sophisticated understanding of a wide number of tradeoffs among multiple actors. As planners contemplate PA expansion, they can consider some of the following tradeoffs: biodiversity representativeness versus ease of implementing protection 
across different ownerships; the economic costs of implementing protection on private lands and public perception of payments; the tradeoff between connecting existing PAs versus protecting isolated but important habitats; tradeoffs between megafauna-heavy conservation areas and other important ecological criteria; tradeoffs between different aspects of biodiversity; and tradeoffs between known critical needs of today versus the less certain estimated needs of tomorrow.

\section{PA data}

Any future research extending the scope of this research should begin by revisiting the PA data used for this analysis. Conservation Areas Reporting and Tracking System [24] is the primary source for information on Canada's PAs. It is unclear, however, to what extent this source is consistent with other sources such as Environment Canada's Environmental Indicators on Protected Areas and the World Database on Protected Areas. Many countries are currently in the process of putting in place formalized reporting structures for PAs. Canada is relatively advanced in this regard although we suspect that the reporting of private PAs is less consistent than that of public PAs.

Protection of natural spaces for habitat, wildlife, and provision of ecosystem services are an important component of land and forest management. Given the stated national target, that "by 2020, at least $17 \%$ of terrestrial areas and inland water are conserved through networks of protected areas and other effective area-based conservation measures" [5] (p. 45); this is a critical period in the history of Canadian land/water management. Ongoing technological advances in remote sensing, GIS, and modeling have made it newly possible to analyze the state of Canada's many landscapes, model the impacts of management decisions, and plan for the future. As a number of different stakeholders and rights-holders collaboratively map current and future land uses onto forest landscapes, science-based conservation targets and spatial prioritizations must be ready and accessible to inform this process. To this end, we have provided an overview of the theoretical framework of spatial conservation prioritization rooted in ecological concepts. By synthesizing the relevant literature in the Canadian context, our objective was to highlight the opportunities available to expand protected areas in Canada, while also broadening engagement and recognizing that conservation is not one-size-fits-all. This work offers a source of options and opportunities to inform conservation agencies with ideas, options, and approaches to expand Canada's PA systems. Multiple actors and agencies, each working within their own stewardship constraints and opportunities, can combine to respond to the stated national priority of protecting more of Canada's natural area.

Author Contributions: This paper was a collaborative effort of the authorial team, with specific, but not limited, roles. Conceptualization, M.A.W., J.C.W.; Methodology, M.A.W., J.C.W., J.A.C., and B.R.; Formal Analysis, B.R., J.C.W., and J.A.C.; Investigation, B.R.; Writing, M.A.W, J.A.C., J.C.W., and B.R.; Funding Acquisition, M.A.W.

Funding: This research received no funding external to government. It was undertaken as part of the "Earth Observation to Inform Canada's Climate Change Agenda (EO3C)" project jointly funded by the Canadian Space Agency (CSA), Government Related Initiatives Program (GRIP), and the Canadian Forest Service (CFS) of Natural Resources Canada (NRCan).

Acknowledgments: Geordie Hobart of the Canadian Forest Service is thanked for assistance with preparation of the manuscript for submission.

Conflicts of Interest: The authors declare no conflicts of interest.

\section{References}

1. Small, C.; Sousa, D. Humans on Earth: Global extents of anthropogenic land cover from remote sensing. Anthropocene 2016, 14, 1-33. [CrossRef]

2. CoP10. Convention on Biological Diversity. In Proceedings of the Conference of the Parties to the Convention on Biological Diversity: Updating and Revision of the Strategic Plan for the Post-2010 Period, Nagoya, Japan, 18-29 October 2010.

3. International Union for Conservation of Nature (IUCN) and United Nations Environment World Conservation Monitoring Centre (UNEP-WCMC). The World Database on Protected Areas (WDPA) October 2012; UNEP-WCMC: Cambridge, UK, 2012. 
4. Jenkins, C.N.; Joppa, L. Expansion of the global terrestrial protected area system. Biol. Conserv. 2009, 142, 2166-2174. [CrossRef]

5. ECCC (Environment and Climate Change Canada). Canadian Environmental Sustainability Indicators: Canada's Protected Areas. Available online: www.ec.gc.ca/indicateurs-indicators / default.asp?lang=en\&n= 478A1D3D-1 (accessed on 20 March 2018).

6. Dudley, N. Guidelines for Applying Protected Area Management Categories; IUCN: Gland, Switzerland, 2008.

7. International Union for Conservation of Nature (IUCN). Guidelines for Protected Area Management Categories. CNPPA with the Assistance of WCMC; IUCN: Cambridge, UK, 1994.

8. International Union for Conservation of Nature (IUCN). Governance of Protected Areas: From Understanding to Action; IUCN: Cambridge, UK, 2014.

9. Andrew, M.E.; Wulder, M.A.; Cardille, J.A. Protected areas in boreal Canada: A baseline and considerations for the continued development of a representative and effective reserve network. Environ. Rev. 2014, 22. [CrossRef]

10. Field, C.B.; Barros, V.R.; Dokken, D.; Mach, K.; Mastrandrea, M.; Bilir, T.; Chatterjee, M.; Ebi, K.; Estrada, Y.; Genova, R. IPCC, 2014: Climate Change 2014: Impacts, Adaptation, and Vulnerability. Part A: Global and Sectoral Aspects; Contribution of Working Group II to the Fifth Assessment Report of the Intergovernmental Panel on Climate Change; Cambridge University Press: Cambridge, UK; New York, NY, USA, 2014.

11. Price, D.T.; Alfaro, R.; Brown, K.; Flannigan, M.; Fleming, R.; Hogg, E.; Girardin, M.; Lakusta, T.; Johnston, M.; McKenney, D. Anticipating the consequences of climate change for Canada's boreal forest ecosystems. Environ. Rev. 2013, 21, 322-365. [CrossRef]

12. Andrew, M.E.; Wulder, M.A.; Coops, N.C. Identification of de facto protected areas in boreal Canada. Biol. Conserv. 2012, 146, 97-107. [CrossRef]

13. Leroux, S.J.; Kerr, J.T. Land-use development in and around protected areas at the wilderness frontier. Conserv. Biol. 2013, 27, 166-176. [CrossRef] [PubMed]

14. ECCC (Environment and Climate Change Canada). Achieving a Sustainable Future: A Federal Sustainable Development Strategy for Canada, 2016-2019. Available online: http:/ / fsds-sfdd.ca/downloads/FSDS_ 2016-2019_Final.pdf (accessed on 20 March 2018).

15. McNamee, K. From Wild Places to Endangered Spaces: A History of Canada's National Parks. In Parks and Protected Areas in Canada: Planning and Management; Dearden, P., Rollins, R., Eds.; Oxford University Press: Don Mills, ON, Canada, 2009; pp. 24-54.

16. Dearden, P.; Rollins, R. Parks and Protected Areas in Canada. In Parks and Protected Areas in Canada: Planning and Management; Dearden, P., Rollins, R., Eds.; Oxford University Press: Don Mills, ON, Canada, 2009; pp. 3-23.

17. Environment Canada. Environmental Indicators. Protected Areas. Available online: https://www.ec.gc.ca/ indicateurs-indicators / default.asp?lang=en\&n=8390800A-1 (accessed on 26 March 2013).

18. Ecological Stratification Working Group. A National Ecological Framework for Canada; Environment Conservation Service, Environment Canada: Ottawa, ON, Canada, 1996.

19. Wiersma, Y.F.; Nudds, T.D. Efficiency and effectiveness in representative reserve design in Canada: The contribution of existing protected areas. Biol. Conserv. 2009, 142, 1639-1646. [CrossRef]

20. Deguise, I.E.; Kerr, J.T. Protected areas and prospects for endangered species conservation in Canada. Conserv. Biol. 2006, 20, 48-55. [CrossRef] [PubMed]

21. Andrew, M.E.; Wulder, M.A.; Coops, N.C. Patterns of protection and threats along productivity gradients in Canada. Biol. Conserv. 2011, 144, 2891-2901. [CrossRef]

22. Ontario Biodiversity Council. Renewing Our Commitment to Protecting What Sustains Us; ntario Biodiversity Council: Peterborough, ON, Canada, 2011.

23. Parks Canada. Parks Canada Agency 2012-13 Departmental Performance Report. Available online: http:/ / www.pc.gc.ca/eng/docs/pc/rpts/rmr-dpr/index.aspx (accessed on 6 November 2018).

24. CARTS. Conservation Areas Reporting and Tracking System. Canadian Council on Ecological Areas; CARTS: Ottawa, ON, Canada, 2011.

25. Slocombe, D.S.; Dearden, P. Protected Areas and Ecosystem-based Management. In Parks and Protected Areas in Canada: Planning and Management; Dearden, P., Rollins, R., Eds.; Oxford University Press: Don Mills, ON, Canada, 2009; pp. 342-370. 
26. Szaro, R.C.; Sexton, W.T.; Malone, C.R. The emergence of ecosystem management as a tool for meeting people's needs and sustaining ecosystems. Landsc. Urban Plan. 1998, 40, 1-7. [CrossRef]

27. Borrini-Feyerabend, G. Governance of protected areas: Innovations in the air. Policy Matters 2003, 12, 92-101.

28. Canadian Council on Ecological Areas (CCEA). Canadian Guidebook for the Application of IUCN Protected Area Categories 2008; CCEA Occasional Paper No. 18. Canadian Council on Ecological Areas Secretariat; CCEA: Ottawa, ON, Canada, 2008; p. 66.

29. Leroux, S.J.; Krawchuk, M.A.; Schmiegelow, F.; Cumming, S.G.; Lisgo, K.; Anderson, L.G.; Petkova, M. Global protected areas and IUCN designations: Do the categories match the conditions? Biol. Conserv. 2010, 143, 609-616. [CrossRef]

30. Swinnerton, G.S.; Buggey, S. Protected Landscapes in Canada: Current Practice and Future Significance. In The George Wright Forum; George Wright Society: Hancock, MI, USA, 2004.

31. Graham, J.; Amos, B.; Plumptree, T. Governance Principles for Protected Areas in the 21st Century; Institute on Governance in Collaboration with Parks Canada and CIDA: Ottawa, ON, Canada, 2003.

32. Office of the Auditor General of Canada. Chapter 4-Ecosystems_Federal Protected Areas for Wildife, 2008 March Status Report of the Commissioner of the Environment and Sustainable Development; Office of the Auditor General of Canada: Ottawa, ON, Canada, 2008.

33. Zimmerer, K.S.; Galt, R.E.; Buck, M.V. Globalization and multi-spatial trends in the coverage of protected-area conservation (1980-2000). Ambio 2004, 33, 520-529. [CrossRef] [PubMed]

34. Bertzky, B.; Corrigan, C.; Kemsey, J.; Kenney, S.; Ravilious, C.; Besançon, C.; Burgess, N. Protected Planet Report 2012: Tracking Progress Towards Global Targets for Protected Areas; IUCN: Gland, Switzerland; UNEP-WCMC: Cambridge, UK, 2012.

35. Boreal Leadership Council. Free, Prior, and Informed Consent in Canada: A Summary of Key Issues, Lessons, and Case Studies towards Practical Guidance for Developers and Aboriginal Communities; Boreal Leadership Council: Ottawa, ON, Canada, 2012.

36. CoP7. Convention on Biological Diversity. In Proceedings of the Conference of the Parties to the Convention on Biological Diversity, Kuala Lumpur, Malaysia, 9-20 February 2004.

37. Liu, X.; Zhang, L.; Hong, S. Global biodiversity research during 1900-2009: A bibliometric analysis. Biodivers. Conserv. 2011, 20, 807-826. [CrossRef]

38. Adams, V.M.; Segan, D.B.; Pressey, R.L. How much does it cost to expand a protected area system? Some critical determining factors and ranges of costs for Queensland. PLoS ONE 2011, 6, e25447. [CrossRef]

39. Maggini, R.; Kujala, H.; Taylor, M.F.J.; Lee, J.R.; Possingham, H.P.; Wintle, B.A.; Fuller, R.A. Protecting and Restoring Habitat to Help Australia's Threatened Species Adapt to Climate Change; National Climate Change Adaptation Research Facility: Gold Coast, Australia, 2013.

40. Australian Government Department of Environment, Water, Heritage and the Arts (DEWHA). The Indigenous Protected Area Program: Background Information and Advice to Applicants. Available online: http:/ / www.environment.gov.au/indigenous/pubs/ipa/ipa-advice.pdf (accessed on 30 March 2014).

41. Government of Australia. Collaborative Australian Protected Area Database. Available online: http:/ / www.environment.gov.au/topics/land/nrs/science-maps-and-data/capad (accessed on 30 March 2014).

42. Hill, R.; Walsh, F.; Davies, J.; Sandford, M. Our Country Our Way: Guidelines for Australian Indigenous Protected Area Management Plans. In Proceedings of the Queensland Coastal Conference, Cairns, Australia, 19-21 October 2011; CSIRO Ecosystem Sciences and Australian Government Department of Sustainability, Water, Environment, Population and Communities: Cairns, Australia, 2011.

43. Ross, H.; Grant, C.; Robinson, C.J.; Izurieta, A.; Smyth, D.; Rist, P. Co-management and Indigenous protected areas in Australia: Achievements and ways forward. Aust. J. Environ. Manag. 2009, 16, 242-252. [CrossRef]

44. Myers, N. Biodiversity hotspots for conservation priorities. Nature 2000, 403, 853-858. [CrossRef] [PubMed]

45. Deutsche Gesellschaft für Internationale Zusammenarbeit (GIZ). Trinational Regional Project Initiative: Strengthening National Protected Area Systems in Colombia, Ecuador and Peru, 2012-2015. Available online: http:/ / www.giz.de/en/worldwide/12717.html (accessed on 30 March 2014).

46. Kukkala, A.S.; Moilanen, A. Core concepts of spatial prioritisation in systematic conservation planning. Biol. Rev. Camb. Philos. Soc. 2013, 88, 443-464. [CrossRef] [PubMed]

47. Lehtomäki, J.; Tomppo, E.; Kuokkanen, P.; Hanski, I.; Moilanen, A. Applying spatial conservation prioritization software and high-resolution GIS data to a national-scale study in forest conservation. For. Ecol. Manag. 2009, 258, 2439-2449. [CrossRef] 
48. Powers, R.P.; Coops, N.C.; Nelson, T.; Wulder, M.A.; Drever, C.R. Integrating accessibility and intactness into large-area conservation planning in the Canadian boreal forest. Biol. Conserv. 2013, 167, 371-379. [CrossRef]

49. Naughton-Treves, L.; Alvarez-Berríos, N.; Brandon, K.; Bruner, A.; Buck Holland, M.; Ponce, C.; Saenz, M.; Suarez, L.; Treves, A. Expanding protected areas and incorporating human resource use: A study of 15 forest parks in Ecuador and Peru. Sustain. Sci. Pract. Policy 2006, 2, 32-44. [CrossRef]

50. Solano, P. Legal Framework for Protected Areas: Peru; IUCN: Gland, Switzerland, 2010.

51. Kareksela, S.; Moilanen, A.; Tuominen, S.; Kotiaho, J.S. Use of inverse spatial conservation prioritization to avoid biological diversity loss outside protected areas. Conserv. Biol. 2013, 27, 1294-1303. [CrossRef] [PubMed]

52. Jackson, S.F.; Gaston, K.J. Incorporating private lands in conservation planning: Protected areas in Britain. Ecol. Appl. 2008, 18, 1050-1060. [CrossRef] [PubMed]

53. Keeley, A.T.; Basson, G.; Cameron, D.R.; Heller, N.E.; Huber, P.R.; Schloss, C.A.; Thorne, J.H.; Merenlender, A.M. Making habitat connectivity a reality. Conserv. Biol. 2018. [CrossRef] [PubMed]

54. Mönkkönen, M.; YLISIRNIÖ, A.L.; Hämäläinen, T. Ecological efficiency of voluntary conservation of boreal-forest biodiversity. Conserv. Biol. 2009, 23, 339-347. [CrossRef] [PubMed]

55. Bennett, D.E.; Pejchar, L.; Romero, B.; Knight, R.; Berger, J. Using practitioner knowledge to expand the toolbox for private lands conservation. Biol. Conserv. 2018, 227, 152-159. [CrossRef]

56. McDonald, J.A.; Helmstedt, K.J.; Bode, M.; Coutts, S.; McDonald-Madden, E.; Possingham, H.P. Improving private land conservation with outcome-based biodiversity payments. J. Appl. Ecol. 2018, 55, 1476-1485. [CrossRef]

57. Di Minin, E.; Macmillan, D.C.; Goodman, P.S.; Escott, B.; Slotow, R.; Moilanen, A. Conservation businesses and conservation planning in a biological diversity hotspot. Conserv. Biol. 2013, 27, 808-820. [CrossRef] [PubMed]

58. Powers, R.P.; Coops, N.C.; Tulloch, V.J.; Gergel, S.E.; Nelson, T.A.; Wulder, M.A. A conservation assessment of Canada's boreal forest incorporating alternate climate change scenarios. Remote Sens. Ecol. Conserv. 2017, 3, 202-216. [CrossRef]

59. Nelson, T.A.; Coops, N.C.; Wulder, M.A.; Perez, L.; Fitterer, J.; Powers, R.; Fontana, F. Predicting climate change impacts to the Canadian boreal forest. Diversity 2014, 6, 133-157. [CrossRef]

60. Holmes, K.R.; Nelson, T.A.; Coops, N.C.; Wulder, M.A. Biodiversity indicators show climate change will alter vegetation in parks and protected areas. Diversity 2013, 5, 352-373. [CrossRef]

61. Powers, R.P.; Coops, N.C.; Morgan, J.L.; Wulder, M.A.; Nelson, T.A.; Drever, C.R.; Cumming, S.G. A remote sensing approach to biodiversity assessment and regionalization of the Canadian boreal forest. Prog. Phys. Geogr. 2013, 37, 36-62. [CrossRef]

62. Whitelaw, G.S.; Eagles, P.F.J. Planning for long, wide conservation corridors on private lands in the Oak Ridges Moraine, Ontario, Canada. Conserv. Biol. 2007, 21, 675-683. [CrossRef] [PubMed]

63. Natural Resources Canada. The State of Canada's Forests: Annual Report 2017. Available online: http:/ / cfs.nrcan.gc.ca/stateoftheforests (11 September 2018).

64. Ontario Parks. Algonquin Park Management Plan Amendment. Ministry of Natural Resources; Ontario Parks: Peterborough, ON, Canada, 2013.

65. Naughton-Treves, L.; Holland, M.B.; Brandon, K. The role of protected areas in conserving biodiversity and sustaining local livelihoods. Ann. Rev. Environ. Resour. 2005, 30, 219-252. [CrossRef]

66. Hummel, M. Protecting Canada's Endangered Spaces; Key Porter Books: Bolton, ON, Canada, 1995.

67. Environment Canada. Canadian Protected Areas Status Report 2000-2005; Environment Canada: Ottawa, ON, Canada, 2006.

68. Canadian Boreal Initiative. The Boreal Forest at Risk: A Progress Report; Canadian Boreal Initiative: Ottawa, ON, Canada, 2003.

69. Canadian Boreal Initiative. The Boreal in the Balance: Securing the Future of Canada's Boreal Region, a Status Report; Canadian Boreal Initiative: Ottawa, ON, Canada, 2005.

70. Groves, C.R.; Kutner, L.S.; Stoms, D.M.; Murray, M.P.; Scott, J.M.; Schafale, M.; Weakley, A.S.; Pressey, R.L. Owning up to our responsibilities: Who owns lands important to biodiversity. In Precious Heritage: The Status of Biodiversity in the United States; Stein, B.A., Kutner, L.S., Adams, J.S., Eds.; Oxford University Press: New York, NY, USA, 2000; pp. 275-300. 
71. Loarie, S.R.; Duffy, P.B.; Hamilton, H.; Asner, G.P.; Field, C.B.; Ackerly, D.D. The velocity of climate change. Nature 2009, 462, 1052. [CrossRef] [PubMed]

72. Turner, M.G. Disturbance and landscape dynamics in a changing world1. Ecology 2010, 91, $2833-2849$. [CrossRef] [PubMed]

73. Frazier, R.J.; Coops, N.C.; Wulder, M.A. Boreal Shield forest disturbance and recovery trends using Landsat time series. Remote Sens. Environ. 2015, 170, 317-327. [CrossRef]

74. Carvalho, S.B.; Velo-Antón, G.; Tarroso, P.; Portela, A.P.; Barata, M.; Carranza, S.; Moritz, C.; Possingham, H.P. Spatial conservation prioritization of biodiversity spanning the evolutionary continuum. Nat. Ecol. Evol. 2017, 1, 0151. [CrossRef] [PubMed]

75. Lehtomäki, J.; Moilanen, A. Methods and workflow for spatial conservation prioritization using Zonation. Environ. Model. Softw. 2013, 47, 128-137. [CrossRef]

76. Leonard, P.B.; Duffy, E.B.; Baldwin, R.F.; McRae, B.H.; Shah, V.B.; Mohapatra, T.K. gflow: Software for modelling circuit theory-based connectivity at any scale. Methods Ecol. Evol. 2017, 8, 519-526. [CrossRef]

77. Pelletier, D.; Clark, M.; Anderson, M.G.; Rayfield, B.; Wulder, M.A.; Cardille, J.A. Applying circuit theory for corridor expansion and management at regional scales: Tiling, pinch points, and omnidirectional connectivity. PLOS ONE 2014, 9, e84135. [CrossRef] [PubMed]

78. Pelletier, D.; Lapointe, M.-É.; Wulder, M.A.; White, J.C.; Cardille, J.A. Forest connectivity regions of Canada using circuit theory and image analysis. PLoS ONE 2017, 12, e0169428. [CrossRef] [PubMed]

79. Margules, C.R.; Pressey, R.L. Systematic conservation planning. Nature 2000, 405, 243-253. [CrossRef] [PubMed]

(c) 2018 by the authors. Licensee MDPI, Basel, Switzerland. This article is an open access article distributed under the terms and conditions of the Creative Commons Attribution (CC BY) license (http://creativecommons.org/licenses/by/4.0/). 